\title{
Low Motivation in Learning Speaking
}

\author{
Aulia Putri \\ English EducationDepartment \\ University of Riau Kepulauan \\ auliaputri1983@yahoo.com
}

\begin{abstract}
This study is aimed to identify the motivation of students in learning Speaking. At first, it is found out that there were 50\% of the students still have low motivation in learning speaking. This research was a qualitative research that describes the condition of students in learning speaking. The writer tried to use another method which is called Cooperative Leaning to enhance students' motivation in learning speaking. After doing it for some period of time, it showed a result that at the end of the course, students who have low motivation decrease to $20 \%$ only. By applying cooperative learning, teacher only plays a little part in speaking in one meeting. The teacher only gives a short explanation about the lesson and then guide the students to do the rest of the activities. The improvement can be seen obviously. The percentage of students who have lack of motivation in speaking decrease significantly. Only $20 \%$ that still feel shy to speak in front of the class, but if we put them in group, they want to participate although still play small parts in their group. They enjoy and are satisfy in learning process. Moreover, they concern with the next speaking activities.
\end{abstract}

Keywords: low motivation, speaking, cooperative learning.

\section{INTRODUCTION}

Speaking is one of the important tools for communication. Human beings can understand each other because they speak up their mind. When communicating one to another, it means people convey something-exchange information, news, ideas, etc. The way they understand others is through their languages. No matter what the language is, as long as they understand each other, it means they have already done the process of communication. One of the important languages that should be mastered in the world is English. Nowadays, speaking English is a must. Like it or not, need it or not, everybody must be able to communicate in this language.

People speak to others in order to convey things that they want to say or to transfer ideas in their mind. Through speaking, they can understand each other so that they can comprehend what others want to say even though they have different languages. Sometimes, using another language is a little bit tricky, confusing, and complicated. English as a second 
language is also considered as a difficult one for learners in order to be a master in this language.

Teaching English as a second language is quite challenging, especially in teaching speaking. Most English students found that they can understand their English teacher, but when they speak to native speaker or called 'real people' they cannot understand them. This condition might be caused by several factors. First, it can be caused by the atmosphere of the class where the main point of speaking activities-discussion, debate, information gap activities, speech, etc- in the class are about grammar point so sometimes English teachers forget that these patterns are not often found in the real interaction. Therefore, English teachers should find things that students need. They should know what kind of activities that works in class which will help students to face the real interaction.

\section{Motivation in Learning Speaking}

Motivation is much needed in doing everything, including in learning something. In learning language, a learner needs motivation because it helps him or her in trying and developing his or her understanding of a new language. With motivation, a learner wants to succeed. So, without it, he or she will certainly fail to make the necessary effort.

Furthermore, Harmer (2003:10) gives some characteristics of good classroom learners, which have: a willingness to listen, a willingness to experiment, a willingness to ask questions, a willingness to think about how to learn and a willingness to accept correction. So, it is part of a teacher's job to encourage students and create a good atmosphere for them to study.

Carlton (2003) in Hanafi (2008) explains some behavioral characteristics which are the indicators of high motivation.

a. Persistence. It is the ability to stay with a task for a reasonably long period of time. A highly motivated child will stay involved for a long period of time, whereas an unmotivated child will give up very easily when not instantly successful. Children learn persistently when they are successful at a challenging task. The art in building persistence is in offering a task that is just challenging enough, but not overwhelming.

b. Choice of challenge is another characteristic of motivation. Children who experience success in meeting one challenge will become motivated, welcoming another. There 
motivated learners will choose an activity that is slightly difficult for them, but provides an appropriate challenge. When they successfully complete such a task, children gain a high level of satisfaction. Unmotivated children (those who have not experienced early success) will pick something that is very easy and ensures an instant success.

c. The amount of dependency on adult is another indicator of motivation. Children with strong intrinsic motivation do not need an adult constantly watching and helping with activities. Children who have a lower level of motivation or are extrinsically motivated need constant attention from adults and cannot function independently. Since independence is an important aspect of quality learning, this dependence on adults will greatly limit children's ability to succeed in school.

d. The last indicator of motivational level is emotion. Children who are clearly motivated will have a positive display of emotion. They are satisfied with their work and show more enjoyment in the activity. Children without appropriate motivation will appear quiet, sullen and bored. They will not take any apparent in their activity and will often complain.

From the above explanation, it can be concluded some indicators of motivation in learning speaking.

1. The students are involved in teaching and learning process.

2. The students are creative.

3. The students ask the questions that do not know.

4. The students are able to work independently.

5. The students enjoy and are satisfy in learning process.

6. The students have willingness to know something. 
7. The students concern with the next speaking activities.

8. The students ask another task after finishing their task.

\section{Teaching Speaking}

According to Donald in his journal about teaching speaking, students need:

a. Practice at using first language or mother tongue strategies, which they do not automatically transfer.

b. An awareness of formal/informal language and practice at choosing appropriate language for different situations.

c. The awareness that informal spoken language is less complex than written language. It uses shorter sentences, is less organized, and uses more 'vague' or non-specific language.

d. Exposure to a variety of spoken text types.

e. The ability to cope with different listening situations. Many listening exercises involve students as 'overhearers' even though most communication is face-to-face.

f. To be competent at both 'message-oriented' or transactional language and interactional language, language for maintaining social relationships.

g. To be taught patterns of real interaction.

h. To have intelligible pronunciation and be able to cope with streams of speech.

i. Rehearsal time. By giving students guided preparation/rehearsal time they are more likely to use a wider range of language in spoken task. 


\section{Cooperative Learning}

Cooperative learning is a successful teaching strategy in which small teams, each with students of different levels of ability, use a variety of learning activities to improve their understanding of a subject. Each member of a team is responsible not only for learning what is taught but also for helping teammates learn, thus creating an atmosphere of achievement. Students work through the assignment until all group members successfully understand and complete it.

One important aspect of creating cooperative learning groups is maximizing the heterogeneity of the students within the small groups. Students should be placed in groups that are mixed by academic skills, social skills, personality, race, and sex. It is often helpful for teachers to work with others who are familiar with their students when groups are being formed. With all of the different aspects of student diversity that need to be taken into consideration, forming groups can seem like an onerous task that will be too difficult for any one person.

\section{RESULTS}

To make someone easy to speak without hesitation is challenging. People want to be good, fluent, and perfect in speaking English. Therefore, they try to add their knowledge and sharpen their skill in speaking by entering an English course or study in English Department. However, they still find difficulties and obstacles in mastering their skill in speaking. Most of them do not have enough capability in speaking English.

Their motivation to speak English is still low. It can be seen from oral activities such as, daily test, speaking class activities, and oral test. Almost $50 \%$ of the students showed low motivation in speaking English. As a consequence, their final score for oral tests are low.

The above condition happens in Speaking Class in English Department of Faculty of Teacher Training and Education, Riau Kepulauan University. They have low motivation in learning speaking. Teachers have tried to do some activities to encourage them to speak, but they still show low motivation in speaking.

Every time the teacher asks them to speak, they will act in the way that the teacher might not expected too. Some of them will remain silent, say 'I do not know', give nodding 
gesture, put hesitating smile in their face, etc. They do not put much effort into their oral tests. Consequently, their speaking achievement at final oral test is still in poor condition.

Dealing with the above problem, the writer applied a strategy which was assumed can enhance students' motivation in speaking English. Since the way of teaching that is applied by new method nowadays is student-center-mode, so the writer tried to develop cooperative learning strategy.

By using this strategy, the chance for the students to speak is bigger than the teacher. Students, who are afraid to speak because they feel shy, found that they are not the center of the activities so they can express themselves.

By applying cooperative learning, teacher only plays a little part in speaking in one meeting. The teacher only gives a short explanation about the lesson and then guide the students to do the rest of the activities. In this way, students sits in group-small or large group- then they involves in speaking activity with their friends which give them a relax atmosphere and a very low tense. The role of the teacher is to monitor their activity, give the help or correction needed, and be a fasilitator and a motivator.

After trying to apply this teaching strategy for several times, the improvement can be seen obviously. The percentage of students who have lack of motivation in speaking decrease significantly. Only $20 \%$ that still feel shy to speak in front of the class, but if we put them in group, they want to participate although still play small parts in their group. They enjoy and are satisfy in learning process. Moreover, they concern with the next speaking activities.

\section{DISCUSSION}

1. Cooperative learning is a suitable strategy for a shy class. It can be used in teaching any subject including teaching foreign language.

2. It helps teacher to do the student-learner-center.

3. The strategy is good because students found it helpful for themself to speak among friends.

\section{REFERENCES}


Donald, Rolf. (__ Teaching speaking skill. Retrieved from: http://www.teachingenglish.org.uk/think/speak_skills.shtml. Accessed on: September 28, 2006.

Hanafi, Tengku. (2008). Improving students' motivation in learning vocabulary by Using crossword puzzle at Grade VIII 6 of SMPN 4 Pekanbaru. Unpublished Thesis. Padang: Graduate Program of State University of Padang.

Heremy, Jeremy. (2003). How to teach English: An introduction to the practice of English language teaching. England: Pearson Education Limited. 